PYTHAGORAS: Jurnal Pendidikan Matematika

Volume 11 - Nomor 2, Desember 2016, (160-168)

Available online at: http://journal.uny.ac.id/index.php/pythagoras

\title{
Keefektifan Cooperative Learning CRH dan NHT Ditinjau dari Sikap dan Prestasi Belajar Matematika Siswa
}

\author{
Noor Laila Atini $^{1}{ }^{*}$, Ali Mahmudi ${ }^{2}$ \\ ${ }^{12}$ Program Studi Pendidikan Matematika, Program Pascasarjana, Universitas Negeri Yogyakarta, \\ Jalan Colombo No. 1, Karangmalang, Yogyakarta 55281 \\ * Korespondensi Penulis. Email: noorlailaatini@gmail.com
}

\begin{abstract}
Abstrak
Penelitian ini bertujuan untuk mendeskripsikan keefektifan cooperative learning tipe Course ReviewHoray (CRH) dan tipe Numbered Heads Together (NHT) yang ditinjau dari sikap siswa terhadap matematika dan prestasi belajar matematika. Penelitian ini adalah penelitian eksperimen semu dengan desain pretest-posttest non equivalent group design. Penelitian ini menggunakan dua kelompok eksperimen. Instrumen yang digunakan untuk mengumpulkan data adalah tes prestasi belajar matematika dan angket sikap siswa terhadap matematika. Untuk menguji keefektifan pembelajaran matematika dengan kedua model pembelajaran digunakan analisis one sample t-test. Selanjutnya untuk membandingkan keefektifan pembelajaran matematika dengan kedua model pembelajaran data dianalisis dengan menggunakan uji $T^{2}$ Hotelling, dan independent $t$-test untuk menentukan model pembelajaran manakah yang lebih efektif. Hasil penelitian menunjukkan bahwa model pembelajaran kooperatif CRH dan NHT efektif ditinjau dari sikap siswa terhadap matematika dan prestasi belajar matematika dan model pembelajaran kooperatif tipe CRH lebih efektif dibanding model pembelajaran kooperatif tipe NHT ditinjau dari sikap siswa terhadap matematika dan prestasi belajar matematika siswa.
\end{abstract}

Kata kunci: pembelajaran kooperatif, CRH, NHT, sikap siswa terhadap matematika, prestasi belajar matematika siswa

\section{The Effectieveness of Cooperative Learning CRH and NHT in Terms of Attitudes and Mathematics Learning Achievement of Students}

\begin{abstract}
This study aims to describe the effectiveness of cooperative learning Course Review Horay (CRH) type and Numbered Heads Together (NHT) type in terms of student's attitudes toward mathematics and mathematics learning achievement. This study was a quasi-experimental study using the pretest-posttest non-equivalent group design. It involved two experimental groups. The data collecting instruments consisted of a mathematics learning achievement test and questionnaires for students' attitudes towards mathematics. To test the effectiveness of the mathematics learning through the CRH and NHT cooperative learning model, the one-sample t-test was carried out. Then, to compare the effectiveness of the two model, the data were analyzed using the $T^{2}$ Hotelling test, and the independent $t$ test to find out which of the two model was more effective. The results of the study show that mathematics learning through the CRH and NHT cooperative learning is effective in terms of student's attitudes toward mathematics and mathematics learning achievement and the CRH cooperative learning model is more effective than the NHT cooperative learning model in terms of student's attitudes toward mathematics and mathematics achievement of student's.
\end{abstract}

Keywords:cooperative learning, CRH, NHT, student's attitude toward mathematics, mathematics achievement of student's.

How to Cite: Atini, N., \& Mahmudi, A. (2016). Keefektifan cooperative learning CRH dan NHT ditinjau dari sikap dan prestasi belajar matematika siswa. PYTHAGORAS: Jurnal Pendidikan Matematika, 11(2), 160-168. doi:http://dx.doi.org/10.21831/pg.v11i2.11182

Permalink/DOI: http://dx.doi.org/10.21831/pg.v11i2.11182 


\section{Pythagoras, 11 (2), Desember 2016 - 161}

Noor Laila Atini, Ali Mahmudi

\section{PENDAHULUAN}

Tujuan pendidikan pada jenjang satuan pendidikan dasar berdasarkan Peraturan Pemerintah No. 23 Tahun 2006 tentang Standar Kompetensi Lulusan adalah untuk meletakkan dasar kecerdasan, pengetahuan, kepribadian, akhlak mulia, serta keterampilan untuk hidup mandiri dan mengikuti pendidikan lebih lanjut. Matematika merupakan mata pelajaran pokok disetiap satuan pendidikan, mulai dari Sekolah Dasar (SD) sampai dengan perguruan tinggi. Berbagai kebijakan telah ditetapkan oleh pemerintah untuk meningkatkan mutu pendidikan dengan melakukan perubahan pada kurikulum, peningkatan kualitas guru, dan penambahan sarana dan prasarana yang mendukung kegiatan belajar dan mengajar. Pemerintah juga menuntut kepada para pemerhati pendidikan untuk meningkatkan kualitas lembaga, pengajar (guru), dan peserta didik (siswa) supaya dapat bersaing dalam kompetensinya masing-masing.

Hadi (2005, p.12) menjelaskan proses pembelajaran matematika yang selama ini terjadi belum sesuai dengan yang diharapkan. Beberapa hal yang menjadi ciri praktik pendidikan di Indonesia selama ini adalah pembelajaran yang berpusat pada guru (teacher centre). Guru menyampaikan materi dengan metode ceramah dan ekspositori sementara siswa mencatatnya pada buku catatan. Pembelajaran matematika seperti ini menyebabkan siswa mengalami kesulitan untuk memahami materi pelajaran matematika yang abstrak. Kondisi ini mengakibatkan mata pelajaran matematika masih dipandang sebagai mata pelajaran yang sulit oleh para pelajar maupun masyarakat umumnya (Orton, 2004, p.178).

Sikap siswa terhadap matematika sangat beragam sekali sesuai dengan unsur sikap yang membangunnya. Unsur kognitif seorang siswa terhadap matematika tergantung dari pelajaran matematika yang banyak jenisnya, sedangkan unsur afektif adalah ada yang merasa senang atau tidak senang terhadap matematika tertentu. Hal ini menyebabkan kecenderungan belajar siswa tidak sama, ada yang belajar dengan konsentrasi ada yang belajar dengan malas pada materi yang sama. Akey $(2006$, p.1) menyatakan sikap memiliki pengaruh besar terhadap hasil belajar siswa. Hal ini terjadi karena aktifitas yang dilakukan siswa didorong oleh suatu kekuatan dari dalam diri siswa. Sebagai salah satu variabel afektif, sikap juga memiliki pengaruh yang signifikan terhadap keberhasilan belajar seseorang. Selaras dengan pernyataan tersebut sikap siswa terhadap matematika sangat menentukan keberhasilan belajar matematika siswa.

Untuk mencapai prestasi dan hasil belajar matematika yang baik, maka perlu juga diimbangi dengan sikap yang positif terhadap matematika. Dalam proses pembelajaran matematika perlu memperhatikan hal-hal yang mempengaruhi sikap siswa terhadap matematika, antara lain materi dan karakteristik matematika itu sendiri, praktik mengajar, aktivitas yang terjadi di dalam kelas, dan guru matematika seperti yang disampaikan oleh Shumway(1980, p.359). Hal penting lainnya adalah kegiatan pembelajaran itu mengarah ke tujuan pembelajaran agar dapat diketahui dari penguasaan siswa terhadap bahan yang diberikan selama kegiatan proses belajar mengajar dengan ditunjukkan oleh prestasi belajar siswa. Karena prestasi atau hasil belajar siswa tersebut dipengaruhi oleh kemampuan kognitif guru dan aspek emosional dalam pengajaran antara lain sikap dan antusiasme seorang guru. (Shumway, 1980, p.437). Dengan demikian, sikap siswa terhadap matematika merupakan faktor yang mempengaruhi prestasi belajar matematika. Oleh karena itu perlu adanya upaya bagaimana membuat siswa memiliki sikap positif terhadap matematika.

Dalam Standar Isi Pendidikan Matematika di SMP No.22 Tahun 2006, mata pelajaran matematika pada satuan pendidikan meliputi aspek-aspek: bilangan, aljabar, geometri dan pengukuran, serta statistika dan peluang. Geometri merupakan salah satu materi di antara beberapa materi pelajaran matematika terutama pada materi segiempat dan segitiga. Pada materi ini siswa telah dikenalkan dengan simbol-simbol dan angka-angka yang menyatakan bilangan tertentu serta garis dan gambar. Trianto (2009, p.18) menyatakan dalam kurikulum di Indonesia terutama dalam mata pelajaran eksak (matematika, fisika, kimia) dalam pengajarannya selama ini terpatri kebiasaan dengan urutan sajian pembelajaran sebagai berikut: diajarkan teori/ definisi/teorema, diberikan contoh-contoh, dan diberikan latihan soal. Kondisi seperti ini tidak akan menumbuhkembangkan aspek kemampuan dan aktivitas siswa seperti yang diharapkan. Akibatnya capaian prestasi yang diperolehtidak seperti yang diharapkan. Berdasarkan hasil penelitian Jailani \& Retnawati (2016, p. 8) bahwa tantangan guru dalam mengembangkan pembelajaran yang mengasah kemampuan berpikir tingkat tinggi (HOTS) adalah guru mengalami kesulitan dalam mengembangkan materi dan 
media pembelajaran dikarenakan belum memiliki pengetahuan yang memadai tentang pembelajaran yang menumbuhkembangkan kemampuan berpikir tingkat tinggi. Adapun tantangan inovasi pembelajaran berorientasi pada masalah yang berasal dari siswa salah satunya adalah siswa kehilangan motivasi dalam belajar dan mengerjakan soal matematika yang berorientasi pada HOTS (Jailani \& Retnawati, 2016, p.5).

Berdasarkan hasil wawancara dengan guru matematika SMP Negeri 12 Yogyakarta, mengatakan bahwa pembelajaran geometri termasuk pembelajaran yang sulit bagi siswanya (khususnya materi bangun datar segiempat dan segitiga). Mengamati proses belajar mengajar di lapangan, pada umumnya sebagian besar pembelajaran segiempat dan segitiga di SMP Negeri 12 Yogyakarta masih menggunakan pembelajaran konvensional dengan menggunakan metode ceramah. Padahal kegiatan pembelajaran harus lebih memperhatikan keaktifan dan kreatif siswa. Dalam pembelajaran konvensional, siswa lebih banyak bekerja secara individu, kurang adanya kesempatan untuk berinteraksi dan bekerja sama antar siswa. Dengan bekerja sama secara tidak langsung siswa sudah belajar berinteraksi, berkomunikasi, dan menghargai pendapat orang lain. Salah satu materi yang cukup sulit dalam pembelajaran matematika adalah geometri. Hal tersebut terungkap dari persentasi penguasaan materi soal matematika yang dikeluarkan oleh Balitbang Kemdikbud untuk ujian nasional sekolah SMP Negeri 12 Yogyakarta.

Daya serap siswa SMPN 12 Yogyakarta terhadap materi bangun datar pada tahun 2011/ 2012 dengan kemampuan yang di uji yaitu menyelesaikan masalah yang berkaitan dengan luas gabungan dua bangun datar sebesar 57,80 dan menghitung luas gabungan dua bangun datar sebesar 68,81. Hal ini masih belum memenuhi standar daya serap nasional berturut-turut yaitu 66,39 dan 75,75 . Untuk mengatasi masalah ini tentunya diberikan model atau pendekatan belajar yang menarik untuk siswa agar dapat meningkatkan pemahaman konsep matematika terutama dalam konsep segiempat dan segitiga serta menentukan ukurannya. Ada banyak sekali model pembelajaran yang menarik dalam proses kegiatan belajar mengajar. Salah satu model pembelajaran yang memberikan kesempatan kepada siswa lebih aktif dankreatif disebut pembelajran kooperatif (cooperative learning). Suprijono (2010, p.54) menjelaskan model cooperative learning memungkinkan siswa untuk mengembangkan pengetahuan, keteram- pilan, dan kemampuan secara penuh dalam suasana belajar yang terbuka dan demokratis. Model pembelajaran kooperatif merupakan salah satu model pembelajaran yang menempatkan siswa sebagai subjek pembelajaran(student oriented), mengembangkan keterampilan-keterampilan kerjasama dan juga sasaran-sasaran konten pembelajaran sehingga diharapkan kepada siswa lebih aktif dalam menyalurkan pengetahuan, gagasan dan menerima gagasan dari temannya. Adanya interaksi yang baik dalam kelompok dapat menumbuhkembangkan sikap positif terhadap pelajaran matemtaika sehingga meningkatkan pemahaman konsep dan prestasinya dalam matematika.

Shumway (1980, pp.373-374) menyatakan sangat penting untuk dapat mengidentifikasi pendekatan yang mendorong sikap positif siswa sehingga meningkatkan prestasi siswa. Hal ini ditekankan pula oleh Jolliffe (2007, p.8) menyatakan bahwa cooperative learning dapat menguntungkan bagi siswa yang berprestasi rendah maupun tinggi yang mengajarkan tugas akademik bersama-sama. Mereka yang berprestasi tinggi mengajari teman-temannya yang berprestasi lebih rendah, sehingga memberikan bantuan khusus dari sesama temannya. Melalui pembelajaran kooperatif diharapkan kepada siswa lebih aktif menyalurkan pengetahuan, gagasan dan menerima gagasan dari temannya. Adanya interaksi yang baik dalam kelompok dapat menumbuhkembangkan sikap positif terhadap pelajaran matematika sehingga dapat meningkatkan prestasi belajar siswa.

Beberapa penelitian yang terkait dalam penelitian ini diantaranyaMaheady, et al (2006, p.25) yang menemukan bahwa dengan pembelajaran kooperatif tipe NHT dapat meningkatkan respons dan prestasi akademik siswa dibandingkan metode tradisional. Zakaria, Chin, \& Daud (2010, p.272) menemukan bahwa pendekatan yang berpusat pada siswa seperti pembelajaran kooperatif dapat meningkatkan prestasi belajar matematika dan sikap belajar siswa terhadap matematika. Penelitian lainnya dilakukan oleh Vaughan (2014, p.359) dengan menunjukkan bahwa pembelajaran kooperatif berpengaruh positif terhadap sikap dan prestasi.

Berdasarkan pembahasan Slavin (2005, p.5) cooperative learning dikenal ada beberapa model. Dalam penelitian ini, peneliti mengambil dua model yaitu Course Review Horay (CRH) dan Numbered Heads Together (NHT). Model pembelajaran $\mathrm{CRH}$ ini merupakan suatu model pembelajaran yang dapat digunakan guru agar 
dapat tercipta suasana pembelajaran di dalam kelas yang lebih menyenangkan, sehingga siswa merasa lebih tertarik. Model CRH diasumsikan dapat memberikan pemahaman konsep materi yang akan dibahas sehingga dapat dikaji secara terarah maka seiring dengan perkembangan dunia pendidikan. Model pembelajaran CRH menjadi salah satu alternatif sebagai model pembelajaran yang mengarah pada pemahaman konsep. Model pembelajaran CRH merupakan salah satu pembelajaran kooperatif yaitu kegiatan belajar mengajar dengan cara pengelompokkan siswa ke dalam kelompok-kelompok kecil. Model pembelajaran CRH yang dilaksanakan merupakan suatu pembelajaran dalam rangka pengujian terhadap pemahaman konsep siswa menggunakan kotak yang diisi dengan soal dan diberi nomor untuk menuliskan jawabannya. Siswa yang paling terdahulu mendapatkan tanda benar langsung berteriak horay atau yel-yel lainnya. Melalui pembelajaran CRH diharapkan dapat melatih siswa dalam menyelesaikan masalah dalam pembentukkan kelompok kecil (Cohen, Brody, \& Shevin, 2007, p.66).

Numbered Heads Together (NHT) adalah struktur yang melibatkan lebih banyak siswa dalam menelaah materi yang tercakup dalam suatu pembelajaran dan mengecek pemahaman mereka terhadap isi pelajaran tersebut. Suprijono (2010, p.93) menjelaskan model ini memiliki prosedur yang ditetapkan secara eksplisit untuk memberi waktu lebih banyak berpikir, menjawab, dan saling membantu sama lain. NHT suatu Model pembelajaran yang lebih mengedepankan kepada aktivitas siswa dalam mencari, mengolah, dan melaporkan informasi dari berbagai sumber yang akhirnya dipresentasikan di depan kelas. NHT pertama kali dikenalkan oleh Spencer Kagan. Model NHT adalah bagian dari model pembelajaran kooperatif struktural, yang menekankan pada strukturstruktur khusus yang dirancang untuk mempengaruhi pola interaksi siswa. Struktur Kagan menghendaki agar para siswa bekerja saling bergantung pada kelompok-kelompok kecil secara kooperatif. Struktur tersebut dikembangkan sebagai bahan alternatif dari sruktur kelas tradisional seperti mangacungkan tangan terlebih dahulu untuk kemudian ditunjuk oleh guru untuk menjawab pertanyaan yang telah dilontarkan. Menurut Cohen, Brody, \& Shevin (2007, p.115) model pembelajaran NHT ini secara tidak langsung melatih siswa untuk saling berbagi informasi, mendengarkan dengan cermat serta berbicara dengan penuh perhitungan, sehingga siswa lebih produktif dalam pembelajaran.

Rumusan masalah dan tujuan dalam penelitian ini adalah untuk mendeskripsikan bagaimana keefektifan cooperative learning tipe $\mathrm{CRH}$ maupun cooperative learning tipe NHT ditinjau dari sikap siswa terhadap matematika dan prestasi belajar matematika siswa kelas VII SMP Negeri 12 Yogyakarta serta untuk mendeskripsikan manakah yang lebih efektif di antara kedua model pembelajaran. Adapun kegunaan penelitian yaitu bagi sekolah, diharapkan dapat digunakan sebagai bahan informasi untuk menentukan salah satu kelebihan dari dua metode pembelajaran yaitu model cooperative learning atau konvensional yang lebih baik untuk digunakan dalam pemahaman konsep segiempat dan segitiga. Bagi guru, diharapkan dapat membantu guru dalam memilih model pembelajaran yang menarik dan relevan dengan pemahaman konsep segiempat dan segitiga. Bagi siswa, diharapkan dapat mengetahui berbagai tekhnik belajar dalam pemahaman konsep segiempat dan segitiga, melatih siswa bekerjasama dalam mengungkapkan pendapat, menghargai kekurangan dan kelebihan siswa lain, menjalin interaksi, serta membangkitkan keaktifan dan kreativitas siswa terhadap matematika. Sebagai bahan referensi bagi peneliti yang akan mengembangkan lebih lanjut terutama untuk model cooperative learning dalam pembelajaran matematika.

\section{METODE}

Jenis penelitian ini adalah penelitian eksperimen semu (quasieksperiment). Karena tidak semua variabel yang muncul dan kondisi eksperimen dapat diatur dan dikontrol secara ketat (full randomize). Variabel terikat dalam penelitian ini yaitu sikap dan prestasi belajar matematika dengan variabel bebas Cooperative Learning tipe CRH dan NHT.

Tempat Penelitian di SMP Negeri 12 Yogyakarta. Penelitian ini mulai pada bulan April-Mei 2014. Populasi dari penelitian adalah seluruh siswa kelas VII yang terdiri atas lima kelas yang berjumlah 177 siswa di SMP Negeri 12 Yogyakarta. Sementara pengambilan sampel penelitian didasarkan pada kelas yang ada. Selanjutnya dipilih secara acak dua kelas, hasilnya yaitu kelas VIIA dengan jumlah siswa 35 orang menggunakan cooperative learning tipe $\mathrm{CRH}$ dan kelas VIIB dengan jumlah siswa 34 orang menggunakan cooperative learning tipe NHT.

Langkah-langkah yang dilakukan dalam penelitan eksperimen berupa: (1) kelompok 


\section{Pythagoras, 11 (2), Desember 2016 - 164}

Noor Laila Atini, Ali Mahmudi

belajar (kelas) yang ada diambil untuk menentukan kelompok eksperimen; (2) memberikan pretest (tes awal) pada waktu yang relatif bersamaan; (3) melakukan pembelajaran dengan pembelajaran kooperatif tipe CRH dan NHT pada kelompok eksperimen; (4) memberikan posttest (tes akhir) pada kedua kelompok dalam waktu yang relatif bersamaan; dan (5) mem-berikan angket sikap terhadap matematika pada kedua kelompok untuk diisi dalam waktu yang relatif bersamaan.

Data sikap siswa terhadap matematika dapat dideskripsikan dan diambil kesimpulan berdasarkan kriteria yang ditentukan. Data hasil tes prestasi belajar matematika yang akan dideskripsikan adalah data pretest dan data posttest. Pretest merupakan tes prestasi belajar matematika siswa yang diberikan kepada kedua kelompok sebelum diberikan perlakuan. Pretest ini bertujuan untuk mengetahui kemampuan awal siswa pada materi yang dieksperimenkan. Posttest merupakan tes prestasi belajar matematika siswa yang diberikan kepada kedua kelompok setelah diberikan perlakuan. Posttest bertujuan untuk mengetahui prestasi belajar matematika siswa setelah diberikan perlakuan.

Instrumen untuk membuktikan kevalidan perangkat pembelajaran terdiri atas lembar validasi RPP, lembar validasi LKS, lembar validasi angket sikap siswa terhadap matematika dan lembar validasi pretest dan posttest prestasi belajar matematika siswa.

Instrumen yang digunakan dalam penelitian ini adalah tes berupa prestasi belajar matematika, dan angket sikap siswa terhadap matematika. Bentuk instrumen tes yang disajikan ada enam soal essay. Tes yang dilakukan oleh siswa ada 2 yaitu: (1) pretest untuk mengukur kemampuan awal siswa sebelum diberikan perlakuan, (2) posttest untuk mengukur kemampuan siswa setelah diberikan perlakuan. Angket sikap siswa terhadap matematika berbentuk daftar cocok (checklist) dan memuat pernyataan-pernyataan sikap siswa terhadap matematika dengan penggunaan model cooperative learning tipe $\mathrm{CRH}$ dan NHT. Model skala sikap yang digunakan dalam penelitian ini adalah skala Likert. Banyaknya skala Likert terdiri atas lima yaitu: Sangat Setuju, Setuju, Ragu-ragu, Tidak setuju dan Sangat tidak setuju.Nilai penskoran untuk item positif yaitu skor lima untuk respon Sangat Setuju, skor empat untuk respon Setuju, skor tiga untuk respon Ragu-ragu, skor dua untuk respon Tidak setuju, dan skor satu untuk respon Sangat tidak setuju. Penskoran untuk item negatif yaitu skor satu untuk respon Sangat setuju, skor dua untuk respon Setuju, skor tiga untuk respon Ragu-ragu, skor empat untuk respon Tidak setuju dan skor lima untuk respon Sangat tidak setuju.

Data penelitian yang dianalisis adalah data pretest dan posttest pada aspek sikap terhadap matematika dan prestasi belajar matematika siswa. Data pretest untuk mengetahui gambaran awal kedua kelompok siswa kemudian selanjutnya post-test untuk mendeskripsikan data perbedaan keefektifan cooperative learning tipe CRH dan NHT. Keefektifan model pembelajaran ditentukan berdasarkan indeks keefektifan. Berdasarkan kriteria ketuntasan minimal (KKM) belajar matematika di SMP Negeri 12 Yogyakarta yaitu siswa dikatakan tuntas belajar apabila mencapai nilai minimal 63,00 untuk skala seratus, maka kriteria pencapaian tujuan pembelajaran prestasi matematika ditetapkan sebesar 63,00 dan model pembelajaran dikatakan efektif jika rata-rata siswa mencapai nilai lebih dari 62,99 .

Untuk data mengenai sikap siswa terhadap matematika akan diperoleh dengan menggunakan instrumen nontes yang berbentuk checklist dengan skala Likert. Data yang diperoleh tersebut digolongkan dalam kriteria berdasarkan skor baku. Penyekoran pada penelitian ini memiliki rentang skor antara 30 sampai dengan 150. Untuk menentukan kriteria hasil pengukurannya digunakan klasifikasi yang ditentukan dengan rata-rata ideal (Mi) dan Standar Deviasi Ideal (SDI).Mi $=(30+150) / 2=$ 90 dan SDI $=(150-30) / 6=20$.

Adapun kriteria sikap siswa terhadap matematika dapat dilihat pada Tabel 1 .

Tabel 1. Kriteria Sikap Siswaterhadap Matematika

\begin{tabular}{cc}
\hline Skor $(\mathbf{X})$ & Kriteria \\
\hline $120<X \leq 150$ & Sangat baik \\
$100<X \leq 120$ & Baik \\
$80<X \leq 100$ & Cukup baik \\
$60<X \leq 80$ & Kurang baik \\
$30 \leq X \leq 60$ & Sangat kurang baik \\
\hline
\end{tabular}

Pembelajaran matematika ditinjau dari sikap siswa terhadap matematika dikatakan efektif jika hasil pengukurannya mencapai skor 90 secara klasikal atau mencapai skor lebih dari 89,99 .

Untuk menyelidiki perbedaan keefektifan model Cooperative Learning tipe $\mathrm{CRH}$ dan NHT ditinjau dari sikap siswa terhadap matematika dan prestasi belajar matematika siswa dilakukan dengan uji multivariat kemudian di- 
lanjutkan uji univariat yaitu independent sample $t$ tes untuk menentukan variabel mana yang berkontribusi terhadap perbedaan keseluruhan. Analisis dilakukan yaitu pada tahap analisis kondisi awal dan analisis kondisi akhir.

\section{HASIL DAN PEMBAHASAN}

Berdasarkan perbandingan sikap awal dan sikap akhir siswa, untuk sikap awal siswa untuk VIIA dan VIIB sebagian besar berkategori baik. Adapun untuk sikap akhir siswa kelas VIIA mengalami kenaikan yang signifikan sehingga memiliki kategori sikap yang sangat baik terhadap matematika. Jadi, dilihat dari hasil persentase perbandingan peningkatatan siswa yang bersikap sangat baik dan yang bersikap baik maka dapat disimpulkan bahwa cooperative learning tipe $\mathrm{CRH}$ lebih baik dari pada cooperative learning tipe NHT ditinjau dari sikap siswa terhadap matematika.

Tabel 2. Perbandingan Sikap Awal dan Sikap Akhir Siswa terhadap Matematika

\begin{tabular}{lcccc}
\hline \multirow{2}{*}{ Kriteria } & \multicolumn{2}{c}{ Sikap awal } & \multicolumn{2}{c}{ Sikap akhir } \\
\cline { 2 - 5 } & Kls A & Kls B & Kls A & Kls B \\
\hline Sangat baik & $11,43 \%$ & $8,82 \%$ & $68,57 \%$ & $38,24 \%$ \\
Baik & $62,86 \%$ & $76,47 \%$ & $22,86 \%$ & $52,94 \%$ \\
$\begin{array}{l}\text { Cukup baik } \\
\text { Kurang }\end{array}$ & $25,71 \%$ & $14,71 \%$ & $8,57 \%$ & $8,82 \%$ \\
$\begin{array}{l}\text { baik } \\
\begin{array}{l}\text { Sangat } \\
\text { kurang baik }\end{array}\end{array}$ & 0 & 0 & 0 & 0 \\
\hline
\end{tabular}

Untuk mendeskripsikan sikap siswa terhadap matematika berdasarkan hasil perhitungan persentase angket sikap siswa terhadap matematika yang ditinjau dari ketiga dimensi yaitu kognitif, afektif, dan konatif dengan pilihan SS (Sangat Setuju), S (Setuju), RR (Ragu-Ragu), TS (Tidak Setuju), dan STS (Sangat Tidak Setuju) dapat disimpulkan bahwa sikap terhadap matematika secara keseluruhan baik kelas VIIA maupun kelas VIIB memiliki persentase yang tinggi. Untuk kelas VIIA dimensi kognitif sebesar $84,4 \%$ atau $26,8 \%$ dari $100 \%$ secara keseluruhan dari ketiga dimensi. Begitu juga halnya dengan dimensi afektif dan konatif bertutut-turut sebesar $84,7 \%$ atau $53,8 \%$ secara keseluruhan dan $81,1 \%$ atau $19,4 \%$ secara keseluruhan. Kelas VIIB secara keseluruhan persentase sikap dari ketiga dimensi berturutturut yaitu $79,5 \%, 81,7 \%$, dan 78,3\% .

Dari ketiga dimensi tersebut maka persentase tertinggi baik kelas VIIA maupun VIIB pada dimensi afektif/ perasaan terhadap belajar matematika, pembelajaran matematika, dan ling- kungan belajar matematika. Hal ini jika dikaitkan dengan ketiga ranah, maka secara keseluruhan siswa memiliki nilai afektif yang cukup tinggi karena dimensi afektif mencakup watak perilaku seperti perasaan, sikap, emosi, dan nilai. Ciri-ciri hasil belajar afektif siswa dari kedua kelas terlihat dalam berbagai tingkah laku, seperti perhatiannnya terhadap mata pelajaran matematika itu sendiri, kedisiplinannya dalam mengikuti mata pelajaran matematika, motivasinya yang tinggi untuk tahu lebih banyak mengenai pelajaran matematika yang di terimanya dan sebagainya. Sikap seseorang dapat dilihat perubahannya bila seseorang telah memiliki kemampuan kognitif yang tinggi, hal inilah yang menjadi faktor penting dan berperan sehingga berdasarkan hasil persentase yang didapat dimensi kognitif mempengaruhi dimensi afektifnya.

Berdasarkan kriteria ketuntasan hasil belajar, rata-rata hasil belajar pada kelompok cooperative learning tipe $\mathrm{CRH}$ dan kelompok cooperative learning tipe NHT sudah memenuhi standar ketuntasan minimal yaitu 63 atau nilai > 62,99. Peningkatan hasil belajar matematika pada kelas cooperative learning tipe $\mathrm{CRH}$ sebesar 77,14 \%. Dari hasil posttest, sebagian besar siswa sudah memenuhi standar ketuntasan minimal yang berjumlah 31 siswa atau 88,57\%. Adapun untuk kelas cooperative learning tipe NHT peningkatan hasil belajar matematika sebesar $64,70 \%$. Dari hasil posttest, sebagian besar siswa sudah memenuhi standar ketuntasan minimal dengan jumlah sebanyak 28 siswa atau $82,35 \%$. Daa tes prestasi belajar matematika siswa akan disajikan dalam Tabel 3 berikut.

Tabel 3. Data Tes Prestasi Belajar Matematika Siswa

\begin{tabular}{lllll}
\hline Deskripsi & \multicolumn{2}{l}{ Kelas VIIA } & \multicolumn{2}{l}{ Kelas VIIB } \\
\cline { 2 - 5 } & (CRH) & \multicolumn{3}{c}{ (NHT) } \\
\cline { 2 - 5 } & Pretest & Postest & Pretest & Postest \\
\hline Rata-rata & 30,14 & 72,83 & 28,24 & 66,91 \\
Standar & 10,746 & 12,141 & 8,119 & 9,209 \\
deviasi & & & & \\
Skor max & 47 & 92 & 50 & 83 \\
Skor min & 8 & 55 & 12 & 40 \\
\hline
\end{tabular}

Untuk melihat keefektifan masing-masing model terhadap prestasi belajar matematika siswa, dilakukan uji one sample t test dengan taraf signifikansi $\alpha=0.05$. Dari hasil analisis menggunakan SPSS 16 for window diperoleh $t_{\text {hitung }}$ $=7,169$. Jika dikaitkan dengan kriteria pengujian, $t_{\text {hitung }}>\mathrm{t}_{\text {tabel }}=1,692$, maka $\mathrm{H}_{0}$ ditolak. Jadi dapat disimpulkan bahwa rata-rata prestasi belajar matematika siswa yang menggunakan 


\section{Pythagoras, 11 (2), Desember 2016 - 166}

Noor Laila Atini, Ali Mahmudi

cooperative learning tipe $\mathrm{CRH}$ lebih besar dari 62.99, atau dengan kata lain cooperative learning tipe CRH efektif terhadap prestasi belajar matematika siswa. Untuk hasil analisis cooperative learning tipe NHT diperoleh $\mathrm{t}_{\text {hitung }}=$ 2,483 . Jika dikaitkan dengan kriteria pengujian, $t_{\text {hitung }}>t_{\text {tabel }}=1,694$, maka $H_{0}$ ditolak. Jadi dapat disimpulkan bahwa rata-rata prestasi belajar matematika siswa yang menggunakan cooperative learning tipe NHT lebih besar dari 62,99, atau dengan kata lain cooperative learning tipe NHT efektif terhadap prestasi belajar matematika siswa.

Untuk melihat keefektifan masing-masing model terhadap sikap siswa terhadap matematika, dilakukan uji one sample t test dengan taraf signifikansi $\alpha=0.05$. Dari hasil analisis menggunakan SPSS 16 for window diperoleh $t_{\text {hitung }}=22,315$. Jika dikaitkan dengan kriteria pengujian, $t_{\text {hitung }}>t_{\text {tabel }}=1,692$, maka $\mathrm{H}_{0}$ ditolak. Jadi dapat disimpulkan bahwa rata-rata sikap siswa terhadap matematika yang menggunakan cooperative learning tipe $\mathrm{CRH}$ lebih besar dari 89,99, atau dengan kata lain cooperative learning tipe CRH efektif ditinjau dari sikap siswa terhadap matematika.Untuk hasil analisis cooperative learning tipe NHT diperoleh $t_{\text {hitung }}$ $=21,056$. Jika dikaitkan dengan kriteria pengujian, $t_{\text {hitung }}>t_{\text {tabel }}=1,694$, maka $\mathrm{H}_{0}$ ditolak. Jadi dapat disimpulkan bahwa rata-rata sikap siswa terhadap matematika yang menggunakan cooperative learning tipe NHT lebih besar dari 89,99 , atau dengan kata lain cooperative learning tipe NHT efektif terhadap sikap siswa pada matematika. Hal ini sesuai dengan hasil penelitian yang dilakukan oleh Martyanti (2016, p.12) bahwa dalam pembelajaran matematika dengan model cooperative learning siswa belajar menyelesaikan masalah bersama dengan teman satu kelompoknya. Dengan bekerja kelompok, siswa dapat saling membantu, bertukar ide, pengetahuan dan pengalaman sehingga masalah lebih mudah diselesaikan.

Data hasil penelitian berupa skor prestasi belajar matematika (posttest) dan sikap siswa terhadap matematika setelah perlakuan, akan dianalisis untuk menguji hipotesis penelitian. Sebelum dilakukan uji hipotesis, maka dilakukan uji normal multivariat dan uji homogenitas.Uji normalitas multivariat menggunakan pendekatan univariat yaitu uji Kolmogorov Smirnov dilakukan untuk mengetahui apakah populasi berdistribusi normal atau tidak. Uji ini dilakukan pada tiap-tiap kelompok yaitu pada kelas VIIA dan VIIB. Berdasarkan hasil meng- gunakan SPSS 16 for windows, diperoleh nilai signifikansi dari pretes pada kelas VIIA, prestasi belajar siswa adalah 0,499, signifikansi sikap siswa terhadap matematika adalah 0.772 . Pada kelas VIIB, prestasi belajar siswa adalah 0,070, signifikansi sikap siswa adalah 0,312.Hasil perhitungan SPSS 16 for window diperoleh signifikansi 0,162>0,05 maka disimpulkan bahwa matriks varians-kovarians kedua populasi adalah sama atau homogen.

Setelah dilakukan uji normalitas dan uji homogenitas serta telah memenuhi kriteria normal dan homogen yang menyatakan bahwa data tersebut adalah berdistribusi normal dan homogen, maka dilanjutkan uji hipotesis multivariat dengan kriteria penerimaan dan penolakan hipotesis adalah $\mathrm{H}_{0}$ ditolak jka nilai signifikansi lebih kecil dari 0,05 atau $F_{\text {hitung }} \geq \mathrm{F}_{\text {tabel }}$ pada taraf signifikansi 5\%. Hasil perhitungan dengan SPSS 16 for windows menunjukkan bahwa angka signifikansi 0,517. Jika dikaitkan dengan kriteria penerimaan, angka signifikansi $>0,05$, maka $\mathrm{H}_{0}$ diterima. Karena itu disimpulkan bahwa sikap siswa terhadap matematika dan prestasi belajar matematika siswa kelas VIIA tidak berbeda dengan sikap siswa terhadap matematika dan prestasi belajar matematika siswa kelas VIIB, atau dengan kata lain kondisi awal subjek penelitian pada kedua kelompok sama ditinjau dari sikap siswa terhadap matematika dan prestasi belajar matematika siswa.

Berdasarkan hasil uji menggunakan SPSS 16 for windows uji Kolmogorov Smirnov, diperoleh nilai signifikansi dari posttest pada kelas VIIA, prestasi belajar matemtika siswa adalah 0,896 dan signifikansi sikap siswa terhadap matematika adalah 0,711. Pada kelas VIIB, prestasi belajar matematika siswa adalah 0,208 dan signifikansi sikap siswa terhadap matematika adalah 0,457. Pengujian homogenitas untuk uji multivariat menggunakan uji Box's $M$ test. Kriteria pengujian ditetapkan bahwa jika angka signifikansi (probabilitas) yang dihasilkan secara bersama-sama lebih besar dari 0,05, maka matriks varians-kovarians kedua populasi adalah sama. Berdasarkan perhitungan nilai signifikansi $0,095>0,05$, maka disimpulkan bahwa matriks varians-kovarians kedua populasi adalah sama atau homogen.

Nilai signifikansi pada prestasi belajar matematika siswa adalah 0,927 , sedangkan sikap siswa terhadap matematika adalah 0,111. Karena nilai signifikansi masing-masing variabel lebih besar dari taraf signifikansi 0,05 maka disimpulkan varians kedua populasi adalah sama, yang 
berkenaan dengan variabel dependen sikap dan prestasi belajar siswa terhadap matematika.

Untuk menyelidiki perbedaan keefektifan cooperative learning tipe $\mathrm{CRH}$ dan NHT ditinjau dari sikap siswa terhadap matematika dan prestasi belajar matematika siswa dilakukan dengan uji multivariate. Kriteria pengujiannya adalah $\mathrm{H}_{0}$ ditolak jika $\mathrm{F}_{\text {hitung }} \geq \mathrm{F}_{(\mathrm{p}, \mathrm{n} 1+\mathrm{n} 2-\mathrm{p}-1 ; 0.05)}$ atau angka signifikansi (probabilitas) yang dihasilkan lebih kecil dari 0,05. Berdasarkan hasil pengujian dengan menggunakan program SPSS 16 for window diperoleh nilai $\mathrm{F}=3,687$ atau nilai signifikansi 0,016 . Jika dikaitkan dengan taraf signifikansi 5\% maka $\mathrm{H}_{\mathrm{o}}$ ditolak. Sehingga dapat disimpulkan bahwa terdapat perbedaan keefektifan cooperative learning tipe CRH dan NHT ditinjau dari sikap siswa terhadap matematika dan prestasi belajar matematika siswa.

Berdasarkan hasil uji hipotesis bahwa terdapat perbedaan keefektifan cooperative learning tipe CRH dan NHT ditinjau dari sikap siswa terhadap matematika dan prestasi belajar matematika siswa, maka dilakukan statistik uji t untuk menentukan kelompok-kelompok tertentu yang berkontribusi terhadap perbedaan secara keseluruhan. Kriteria yang digunakan adalah kriteria Bonferroni dimana taraf siginfikansinya adalah $\alpha / \mathrm{p}(\mathrm{p}=2)$ jadi untuk $\alpha=0,05$ untuk masing-masing uji $t$ digunakan kriteria $0,05 / 2=$ 0,025 . Kriteria pengujiannya adalah $\mathrm{H}_{0}$ ditolak jika $\mathrm{t}_{\text {hitung }} \geq \mathrm{t}_{(0,025 ; \mathrm{n} 1+\mathrm{n} 2-2)}$ atau nilai signifikansi lebih kecil 0,025. Hasil uji hipotesis menggunakan bantuan SPSS 16 for window menunjukkan nilai $\mathrm{t}=2,413$ atau nilai signifikansi adalah 0,019 . Jika dikaitkan dengan nilai signifikansi 0,025 maka $H_{o}$ ditolak. Sehingga dapat disimpulkan bahwa cooperative learning tipe $\mathrm{CRH}$ lebih efektif dibanding cooperative learning tipe NHT ditinjau dari sikap siswa terhadap matematika.

Untuk melihat manakah yang lebih efektif antara kedua model pembelajaran berdasarkan hasil analisis dengan kriteria yang digunakan adalah kriteria Bonferroni dimana taraf siginfikansinya adalah $\alpha / \mathrm{p}(\mathrm{p}=2)$ jadi untuk $\alpha=0,05$ untuk masing-masing uji $t$ digunakan kriteria $0,05 / 2=0,025$. Kriteria pengujiannya adalah $\mathrm{H}_{0}$ ditolak jika $t_{\text {hitung }} \geq \mathrm{t}_{(0,025 ; \mathrm{n} 1+\mathrm{n2} 2-2)}$ atau nilai signifikansi lebih kecil 0,025. Hasil Uji hipotesis menggunakan bantuan SPSS 16 for window menunjukkan nilai $\mathrm{t}=2,833$ atau nilai signifikansi adalah 0,006. Jika dikaitkan dengan nilai signifikansi 0,025 maka $\mathrm{H}_{\mathrm{o}}$ ditolak. Sehingga dapat disimpulkan bahwa cooperative learning tipe CRH lebih efektif dibanding cooperative learning tipe NHT ditinjau dari prestasi belajar matematika siswa.

\section{SIMPULAN DAN SARAN}

\section{Simpulan}

Simpulan dari penelitian ini adalah cooperative learning tipe CRH maupun NHT efektif ditinjau dari sikap terhadap matematika dan prestasi belajar matematika pada siswa kelas VII SMP Negeri 12 Yogyakarta. Cooperative learning tipe CRH lebih efektif dibanding NHT ditinjau dari sikap terhadap matematika dan prestasi belajar matematika pada siswa kelas VII SMP 12 Yogyakarta.

\section{Saran}

Hal-hal yang dapat disarankan setelah melakukan penelitian ini adalah kedua model pembelajaran kooperatif baik tipe CRH maupun tipe NHT efektif dalam pembelajaran. Oleh karena itu disarankan dalam penerapannya banyak menggunakan berbagai sumber dalam merancang model serta aturan permainan dengan baik, agar proses pembelajaran berlangsung dengan baik dan lancar. Disarankan kepada guru untuk menggunakan cooperative learning tipe $\mathrm{CRH}$ dalam pembelajaran matematika, dengan memberikan ruang gerak bagi siswa membentuk permainan kelompok maupun individu, sehingga mereka juga mampu menemukan konsep secara kelompok maupun individual.

\section{DAFTAR PUSTAKA}

Akey, T.M. (2006). School context, student attitudes and behaviour, and academic achievement: An exploratory analysis. New York, NY: Institute of Education Sciences.

Balitbang Kemdikbud (2012). Daya serap siswa SMPN 12 Yogyakarta terhadap materi bangun datar. Sumber: Data Sekolah.

Cohen, E.G., Brody, C.M., \& Shevin, M.S. (2007). Teaching cooperative learning the challenge for teacher education. New York, NY: Diane Ganeles.

Depdiknas (2006). Peraturan Pemerintah RI Nomor 22, Tahun 2006, tentang Standar Isi.

Depdiknas (2006). Peraturan Pemerintah RI Nomor 23,Tahun 2006, tentang Standar Kompetensi Lulusan. 


\section{Pythagoras, 11 (2), Desember 2016 - 168}

Noor Laila Atini, Ali Mahmudi

Hadi, S. (2005). Pendidikan matematika realistik dan implementasinya. Yogyakarta.

Jailani \& Retnawati, H. (2016). The challenges of junior high school mathematic teachers in implementing the problem-based learning for improving the higher-order thinking skills. The Online Journal of Counseling and Education, 5(3), 1-13.

Jolliffe, W. (2007). Cooperative learning in the classroom putting it into practise. London: Paul Chapman Publishing.

Maheady, L. et.al, (2006). The effects of Numbered Heads Together with and without an incentive package on the science test performance of a diverse group of sixth graders. Journal of Behavioral Education, Vol. 15, No. 1, 25-39. Diambil pada tanggal 4 Oktober 2014, dari http://link.springer.com.scihub.org/article/10.1007/s10864-0059002-6.

Martyanti, A. (2016). Keefektifan pendekatan problem solving dengan setting STAD dan TAI ditinjau dari prestasi dan selfconfidence. Jurnal Riset Pendidikan Matematika, 3(1), 1-15. doi:http://dx.doi.org/10.21831/jrpm/v3i1.9 825 .

Orton, A. (2004). Learning mathematics $3^{\text {rd }}$ edition. Issues, theory, and classroom practice. London, New York: British library.
Shumway, R.J. (1980). Research in mathematics education. Virginia, VA: The National Council of Teacher of Mathematics, Inc.

Slavin, R.E. (2005). Cooperative learning "Theori, research and practice. London: Allyn and Bacon.

Suprijono, A. (2010). Cooperative learning Teori dan aplikasi PAIKEM. Yogyakarta: Pustaka Pelajar.

Trianto. (2009). Mendesain model pembelajaran inovatif-progresif: konsep, landasan dan implementasinya pada kurikulum tingkat satuan pendidikan (KTSP). Jakarta: Kencana perdana media group.

Vaughan, W. (2014). Effects of cooperative learning on achievement and attitude among students of color. The Journal of Educational Research, 95:6, 359-364, Diambil pada tanggal 22 September 2014, dari

http://dx.doi.org/10.1080/0022067020959 6610.

Zakaria, E., Chin L.C., \&Daud,Md.Y. (2010). The effects of cooperative learning on students mathematics achievement and attitude towards mathematics. Journal of Social Sciences, Vol 6, Issue 2, P 272275. Diambil pada tanggal 27 September 2014 ,

dari http://thescipub.com.scihub.org/abstract/1 0.3844/jssp.2010.272-275. 